\title{
SPROSTITEV IN USTVARJALNOST V ŠOLI
}

(Helena Bizjak)

\begin{abstract}
V
zadnjem času pogosto slišimo očitke, da v naših šolah učence preveč obremenjujemo. Predvsem pa se od učencev zahteva preveč učenja na pamet. Poudarja se namreč le racionalna sfera. Po drugi strani pa je čedalje očitneje, da se mladi spoprijemajo s problemom razvrednotenja vrednot. Stare so zavrgli, toda tudi novih še ni, ki bi se jih lahko oprijeli in po katerih bi se ravnali. Tako se je mlada generacija znašla $v$ precepu, $v$ nekakšnem praznem prostoru, kjer le redki posamezniki najdejo izhod. In kako v takšnih nenaklonjenih časih izboljšati kvaliteto bivanja?
\end{abstract}

Knjiga Helene Bizjak nam omogoča svojevrsten vpogled $\mathrm{v}$ zadevno problematiko, začenši z razpravo o celostni vzgoji človeka. Skozi posamezna poglavja nas avtorica skuša pripeljati do spoznanja, kako pomembna je za človeka sprostitev. Lotila se je zapletene in nehvaležne ter še vedno $v$ temo zavite razprave o polarnosti človekovega telesa.

Kako naj torej šola postane prijazna učencu? $S$ pravo vzgojo. Avtorica zastopa stališče, da se vzgoja lahko začne šele, ko učitelj najde pot do mladostnikove notranjosti. V razmišljanje ponudi več vzgojnih oblik, pri čemer kaže še posebej poudariti vzgojo za mišljenje. $\mathrm{Ni}$ torej vseeno, kaj in kako mislimo. Od načina mišljenja je odvisno, ali spadamo med pesimiste ali optimiste.

Piše lahkotno, tako da se zdi še tako velika strokovnost dostopna vsakemu človeku. Avtoričin namen je predvsem seznaniti učitelje in vzgojitelje s tehnikami sproščanja in na tej podlagi predstaviti tudi metode za povečanje ustvarjalnosti.

$\mathrm{V}$ delu se čuti vpliv različnih kultur in vrst razmišljanja. Izhaja iz spleta pogledov na človeka, značilnih za zahodni svet, in pojmovanja človeka, značilnega za vzhodni svet, in se pri dotakne tudi religij obeh svetov. Tem se sploh ne skuša izogniti, kar je lahko morda za koga tudi moteče in predvsem nenavadno.
Posebej moramo opozoriti tudi na sestavo knjige. Vsebina je zajeta $\mathrm{v}$ treh zaokroženih delih in vsak odpira drug vidik problematike celostne vzgoje. $V$ prvem delu govori o življenjski energiji in človekovem telesu ter bralcu predstavi morda malo nenavadno sliko človeka, pri čemer se čuti močan vpliv Steinerjeve waldorfske pedagogike. $V$ drugem delu nam predstavi vaje ozaveščanja, kamor spadajo metode sproščanja, za izboljšanje spomina in še mnoge druge. $\mathrm{V}$

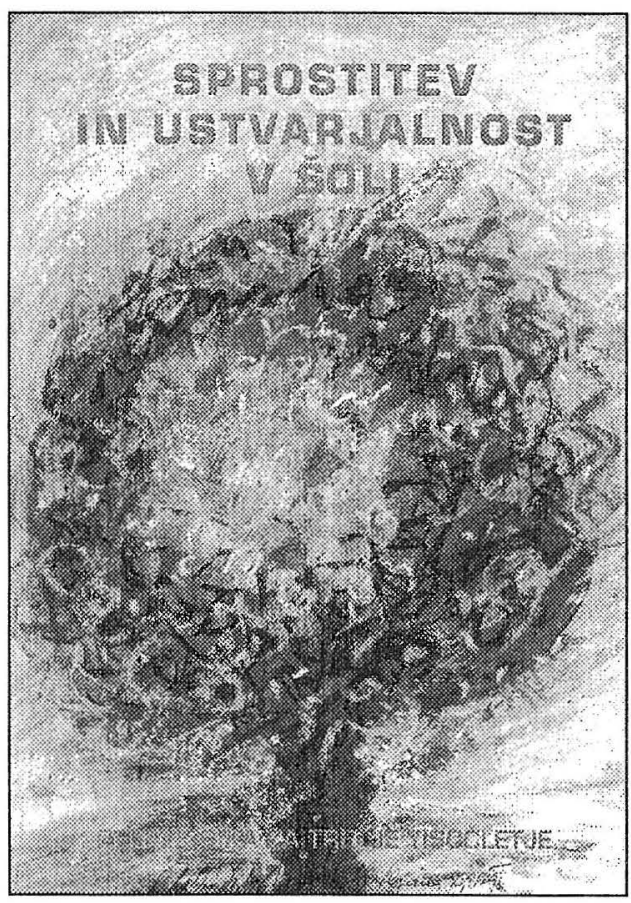
tretjem delu pa bralcu predstavi meditacijo kot način sprostitve in poudarja, kako lahko meditacijske metode uspešno uporabljamo $\mathrm{v}$ šoli. Knjigi je priložena tudi kaseta.

Iz besedila je razvidno, da želi avtorica bralca prepričati, kako pomembna je sproščenost, o pomenu kratkih obdobij brez pritiskov za zdrav osebnostni razvoj učencev.

Knjiga je vpeta $v$ naš čas. Zavod za šolstvo namreč že nekaj let namenja posebno pozornost celostni vzgoji v šoli. Delo Helene Bizjak odstira še eno pot k celostni vzgoji, zato jo lahko vsi tisti, ki se trudijo doseči cilj, uporabljajo kot priročno literaturo.

Njegova velika praktična vrednost pa je predvsem $\mathrm{v}$ velikem številu vaj in metod ter drobnih nasvetov, ki nam lahko pomagajo do sproščenega stanja. Delo je zanimivo že zaradi tega, ker predstavlja pravzaprav redko tematiko v strokovni literaturi, sproščanje v šolah.

mag. Daniela Brečko Gospodarski vestnik 